\title{
Concepts, design and implementation of Reverse Logistics Systems for sustainable supply chains in Brazil
}

\author{
Henrique Luiz Corrêa \\ Rollins College \\ hcorrea@rollins.edu \\ Lucia Helena Xavier \\ Fundação Joaquim Nabuco \\ lucia.xavier@fundaj.gov.br
}

\begin{abstract}
There is growing social pressure for organizations to reduce their rates of consumption of nonrenewable natural resources and in parallel, to also reduce the release of post-production and postconsumption waste to landfills, water bodies and air, thereby causing damage to the environment. To respond to the pressure it is necessary that organizations' operations prioritize the " $3 R$ " goals: Reduce, Reuse and Recycle.

In this context, the so called reverse logistics flows have grown in importance in the study of supply chains. Examples are the components and materials that are collected after they are consumed or used. Instead of being sent to the landfill companies use reverse logistics to transport them back in supply chains to be reused or, recycled and reincorporated as secondary input material for new production. This article aims, through the review of related legislation in Brazil, relevant literature and a number of Brazilian and international case studies to develop a basic framework to be used in the development and implementation of reverse logistics systems (RLS).
\end{abstract}

Keywords: Reverse logistics, closed loop supply chain, sustainability, Brazil 


\section{Sustainable development: a brief history}

How to consider environmental issues related to production without negatively impacting the economic performance of organizations? That was the main issue that permeated discussions about the environment throughout the 1970s and 1980s when the concept of sustainable development was proposed (Brundtland Report, 1988). The notion of sustainable development suggests a more balanced approach between economic growth and environmental conservation. Innovative environmental management tools have since been developed and proposed to support better environmental assessment and management to be used by companies, governments and NGO's.

With increasing pressure from organized society for a more sustainable and responsible environmental management some companies resented the lack of internal capabilities and guidelines to make their logistics function to become more environmentally responsible. Also, they lacked mechanisms that allowed them to have some kind of influence on the behavior of other members of their supply chains in order to obtain better environmental management and performance of their supply chain as a whole. In the '90s, partly in response to such shortage of capabilities and guidance, international certification procedures such as those of the ISO 14000 were developed. They address various aspects of environmental management, by offering practical tools for businesses and organizations seeking to identify and manage their environmental impacts and continually improve their environmental performance. (http://www.iso.org/iso/iso14000 ISO official website, accessed September 14, 2012).

Many companies around the world were guided by the ISO 14000 series standards to adjust their own operations. The ISO 14000 standards were also used as guidelines when such companies required their supply chain partners (such as suppliers and customers) to also do their part in regard to sustainability efforts. This caused an increase in the demand on companies to adapt the traditional financial and market-driven criteria towards more environmentally friendly ones when making decisions. Exporting companies had to adapt their products and processes to legal environmental requirements, not only of their own countries but also to the ones of the countries with which they traded their products and services.

\section{The logistics - environment interaction}

In the United States in the 90s, the establishment of legal environment-related limits such as maximum emissions for certain modes of transportation in some states can be considered an important milestone in the interaction between logistics and the environment.

Bowman (1995) mentions large companies such as Du Pont and Santa Fe Railway as pioneers in the development of strategies and techniques for security and environmental preservation in the transport of dangerous goods and in air emissions.

The Protocols of Montreal in the 80s (http://www. epa.gov/ozone/intpol/, accessed April 9, 2013) and Kyoto in the 90s (http://www.kyotoprotocol.com/, accessed April 9, 2013) were instrumental in setting more comprehensive targets of limits for atmospheric emissions, including by logistic operations. Management goals were then established within organizations considering the need for reducing Greenhouse Gases (GHGs) atmospheric emissions. Organizations of the signatory countries had to adapt by refocusing management goals and allocating / managing resources in a more environmentally efficient way. However, it was the Basel Convention in the 90s (http://www.basel.int/TheConvention/ Overview/TextoftheConvention/tabid/1275/ Default.aspx accessed April 09, 2013) - of which Brazil is a signatory - that established standards for the most important interface between logistics and environmental considerations through the establishment of limitations to the trans boundary (across country borders) movement of hazardous waste.

The aforementioned protocols have had important impact on organizational management and have also influenced public policy in many countries.

Some developed countries complied with their agreed emission limits by promoting the migration of industrial parks to other countries where the legal and regulatory requirements established no or less stringent restrictions on air emissions. Through this mechanism, many polluting manufacturing operations of multinational companies have been relocated to developing countries.

The Basel Agreement also had an impact on international trade policies of signatory countries, since to a certain extent the movement of hazardous 
waste came to be regulated and limited. The central objective of the Basel agreement was to establish limits on the migration of waste from developed countries to developing countries which however still occurs today. Countries in Africa and Asia, for example, are still the main destination of waste of electrical and electronic equipment (WEEE), as illustrated in Figure 1.

\section{Electronic waste export}

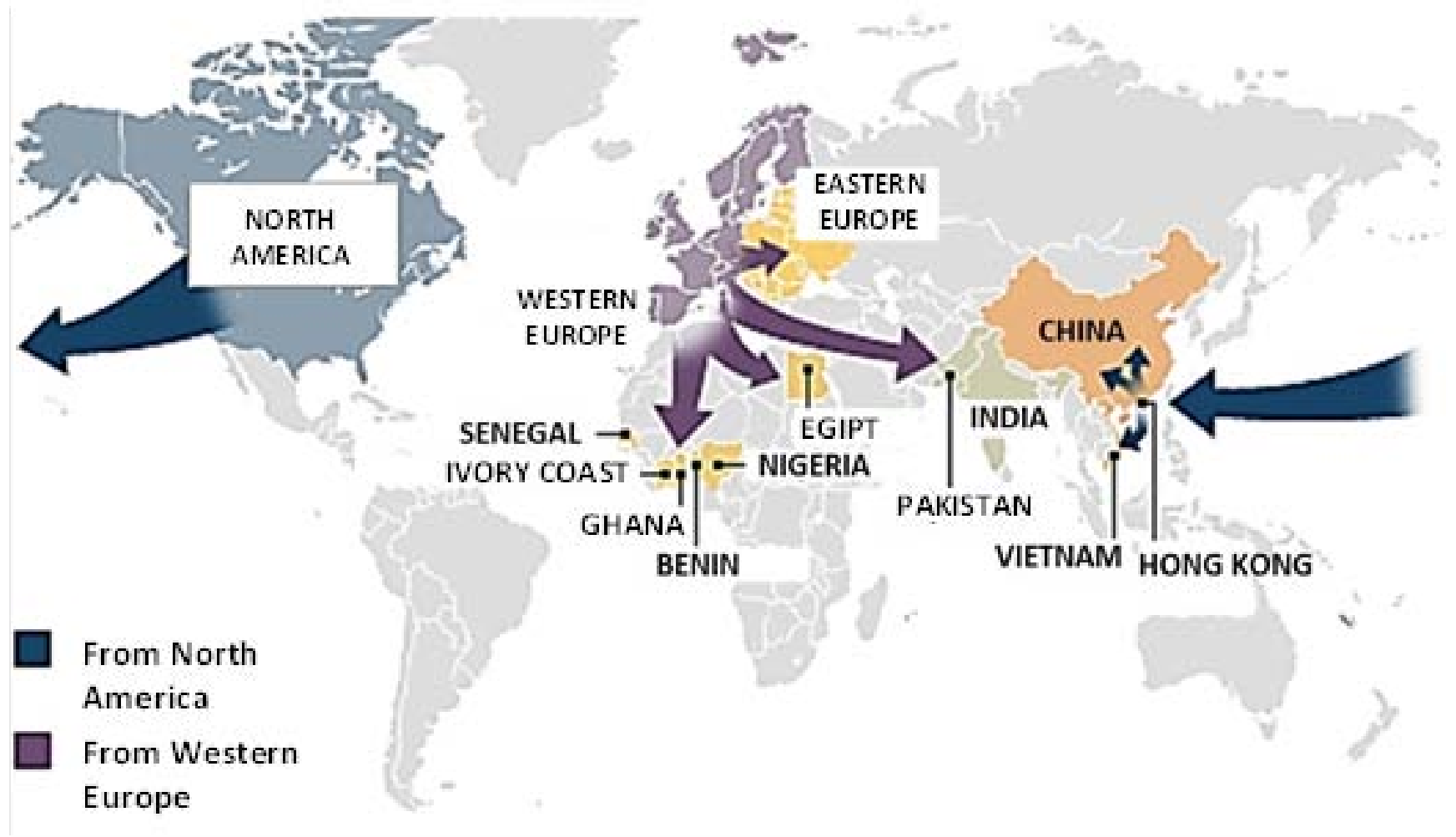

Figure 1 Exports of electronics waste in the world.

Source: modified from Greenpeace and Basel Action Network (BAN) apud Greenfudge (2010).

Part of this waste is characterized as "hazardous waste" due to the potential for environmental contamination by toxic materials therefore requiring environmentally appropriate disposal. The shipping of such waste to countries where legislation does not appropriately regulate disposal is actually a mechanism to transfer the damage, as contemplated in the Basel Agreement.

De Brito and Dekker (2003) propose a framework where post-consumer products should as much as possible be allocated into repair, refurbishing and remanufacturing rather than sent to landfill disposal. Reverse logistics would thus be a key competence in supply chains.

\section{The regulation of reverse logistics in Brazil}

In Brazil specific environmental laws have significantly impacted production systems in different industries. Below some of these regulatory mechanisms are briefly discussed.

\section{Aspects of environmental regulation in Brazil}

During the 1980s and the first half of the 1990s, the National Environment Policy, instituted by Law No. 6938 of 1981 became the main regulatory framework to deal with environmental management in the country.

The law, passed during the military government was a modern and innovative instrument as compared to environmental standards then in force in Latin America. Still, the references in the law to socio-economic development, national security and the protection of dignity of human life reflects the views of military strategic thinking of the time and consequently also assumes unlimited growth prospects (some would say, even at the expense of 
environmental protection and sustainability).

Brazil's Constitution of 1988 included specific articles about environmental protection (Articles 23 and 225) by assigning to municipalities, states and federal government responsibility to protect the environment, combat pollution in any of its forms and preserve the forests, fauna and flora of the country as well as to preserve and restore the essential ecological processes and bio-diversity.

The National Policy of Water Resources established by Law No. 9433 of 1997 regulated the granting and charging for the use of water resources by private enterprise, as well as on compensation for municipalities when companies exploit their other environmental resources.

Through this law, mechanisms for managing water resources were defined and also were mechanisms for the prevention of pollution from the discharge of sewage and waste (liquid or gas) in water bodies. Law No. 9605 of 1998, known as the Environmental Crimes Act regulates the penalties and fines (normally proportional to the damage) to account for environmental impacts and considers individuals as being responsible for the environmental impact of industrial activity. For example, the manager of an industrial enterprise can be personally held responsible and criminally charged for impacts resulting from the environmentally inappropriate management of company activities.

By Law No. 11445 of 2007 guidelines and Policy on National Sanitation were instituted. By contemplating processes inherent to solid waste management and also by specifying social control as the mechanism for action, this law is directly related to reverse logistics. Its regulations regarding the inclusion of associations and cooperatives of pickers of recyclable materials in the process of waste management on a large scale represented an important milestone. Also through Law 11445 the National Movement of Recyclable Materials (MNCR) found legitimacy to act through associations and cooperatives of pickers.

The role and work of pickers still appear in Decree 5940 of 2006 which regulates the management of recyclable materials in federal offices and buildings. According to this decree, such materials should be dealt with through associations and cooperatives of pickers as a means to favor social inclusion. This aspect is taken into Law 12305 of 2010 as discussed later in this article.

\section{Regulation of "reverse logistics" in Brazil}

The main piece of legislation that defines the concept and implementation of reverse logistics systems in Brazil is Law No. 12305 of 2010 that establishes the National Policy on Solid Waste (PNRS). In this law, producers, importers and traders are considered as co-responsible for environmental impacts from production, transportation, consumption and disposal of products. The letter of PNRS starts by altering the Environmental Crimes Law, emphasizing the accountability and assignment of fines and penalties for environmental damage caused by improper solid, liquid or gaseous waste management.

Efficient environmental management avoids both the abuse of natural resources and environmental degradation. Environmental management is a necessity from the perspective of maintaining and improving quality of life today, but also because only an eco-efficient use of resources today will be able to preserve its potential use by future generations.

For almost two decades the bill on PNRS remained under discussion in congress before being approved in 2010. Throughout this period many states and municipalities have developed their own regulatory mechanisms. Probably the more local initiatives to pass state and city-level specific regulations for waste management even before the establishment of a national policy through federal legislation was the result of increased market pressure and of greater environmental awareness by local communities.

Many states and municipalities in Brazil have regulations about solid waste management but few mention the concept of reverse logistics. Some of these are now being adapted to the requirements of PNRS (see Table 1). 
Table 1 State laws and decrees on the disposal of solid waste in Brazil

\begin{tabular}{|c|c|}
\hline Law / Ordinance & Establishes \\
\hline \multicolumn{2}{|l|}{ State of Rio Grande do Sul } \\
\hline 9493/1992 & Selective collection and recycling as relevant social activities. \\
\hline $9921 / 1993$ & Solid waste management in the state of Rio Grande do Sul \\
\hline 38356/1998 (State Decree) & $\begin{array}{l}\text { Legislates about waste management in the State of Rio } \\
\text { Grande do Sul. }\end{array}$ \\
\hline $12381 / 2005$ & Prohibition of sales of imported used tires. \\
\hline $13306 / 2009$ & $\begin{array}{l}\text { Procedures for batteries, lamp bulbs and other products } \\
\text { containing heavy metals. }\end{array}$ \\
\hline \multicolumn{2}{|l|}{ State of Paraná } \\
\hline $10182 / 1992$ & $\begin{array}{l}\text { That all products packaged in glass, plastic, Styrofoam or cans, } \\
\text { manufactured in the state of Paraná must have the application } \\
\text { of the seal-symbol "Recycling of materials" in the packaging }\end{array}$ \\
\hline $12493 / 1999$ & Policy for managing industrial solid waste \\
\hline \multicolumn{2}{|l|}{ State of Rio de Janeiro } \\
\hline 2011/1992 & The mandatory implementation of waste reduction programs \\
\hline 2030/1992 & $\begin{array}{l}\text { The application of the symbol-seal for recycling of glass, } \\
\text { plastic, cans, paper and cardboard used in packaging of } \\
\text { products manufactured in the state of Rio de Janeiro }\end{array}$ \\
\hline $3206 / 1999$ & $\begin{array}{l}\text { Rules and procedures for the service of collecting, recycling } \\
\text { and final disposal of bottles and plastic containers in the state } \\
\text { of Rio de Janeiro }\end{array}$ \\
\hline $3369 / 2000$ & Standards for the disposal of plastic bottles and other measures \\
\hline $4191 / 2003$ & State Policy on Solid Waste \\
\hline 31416/2009 (State Decree) & $\begin{array}{l}\text { Integrated Waste Management Plan, regarding reduction } \\
\text { of Green House Gases emissions in the city of Rio de Janeiro. }\end{array}$ \\
\hline $\begin{array}{l}\text { 30624/2009 (Municipal } \\
\text { Decree) }\end{array}$ & $\begin{array}{l}\text { Selective waste collection at the source and allocation to } \\
\text { cooperatives of waste pickers. }\end{array}$ \\
\hline
\end{tabular}




\begin{tabular}{|c|c|}
\hline \multicolumn{2}{|l|}{ State of Pernambuco } \\
\hline $12114 / 2001$ & $\begin{array}{l}\text { Repurchase, reuse, recycling and disposal of bottles and plastic } \\
\text { containers in the state of Pernambuco }\end{array}$ \\
\hline 35760/2010 (State Decree) & $\begin{array}{l}\text { Inter-institutional Technical Commission - CTI for the } \\
\text { management of solid waste in the state of Pernambuco }\end{array}$ \\
\hline $14236 / 2010$ & State Policy on Solid Waste \\
\hline \multicolumn{2}{|l|}{ State of Mato Grosso } \\
\hline $7862 / 2002$ & State Policy on Solid Waste \\
\hline \multicolumn{2}{|l|}{ State of Ceará } \\
\hline $13103 / 2001$ & State Policy on Solid Waste \\
\hline \multicolumn{2}{|l|}{ State of Minas Gerais } \\
\hline $13766 / 2000$ & Enforcement of selective waste collection \\
\hline $18031 / 2009$ & State Policy on Solid Waste \\
\hline \multicolumn{2}{|l|}{ State of Espírito Santo } \\
\hline $9264 / 2009$ & State Policy on Solid Waste \\
\hline \multicolumn{2}{|l|}{ State of Sao Paulo } \\
\hline $4091 / 1984$ & Administrative penalty for inadequate waste management. \\
\hline $13316 / 2002$ & $\begin{array}{l}\text { Collection, disposal and reuse of packaging, plastic bottles } \\
\text { and tires and other measures }\end{array}$ \\
\hline $12300 / 2006$ & State Policy on Solid Waste and sets guidelines \\
\hline $57817 / 2012$ & Implementation of the State Program of Projects Solid Waste \\
\hline $58107 / 2012$ & Strategies for sustainable development in Sao Paulo state. \\
\hline
\end{tabular}

The National Policy on Solid Waste (PNRS) defines reverse logistics as:

"Instrument of economic and social development characterized by a set of actions, procedures and means to facilitate the collection and recovery of solid waste from the business sector to reuse it in their own (or other) production cycles, or for environmentally appropriate disposal" (Law No. 12305 of 2010)

The disposal of solid waste may therefore include alternatives with or without reuse. "Environmentally appropriate disposal" should be interpreted as alternatives including reuse, recycling, composting, energy recovery or other forms of disposal provided that they are authorized by the competent government bodies, such as those that make up the National Environmental System (SISNAMA). Final disposal although also interpreted as a possible destination, is restricted to un-usable residues, i.e. it refers to that category of waste that is not capable of being reused or reprocessed for reuse.

The responsibility of the agents involved in the reverse chain is an aspect that has been widely debated and that is enshrined in legislation (see Figure 2). 


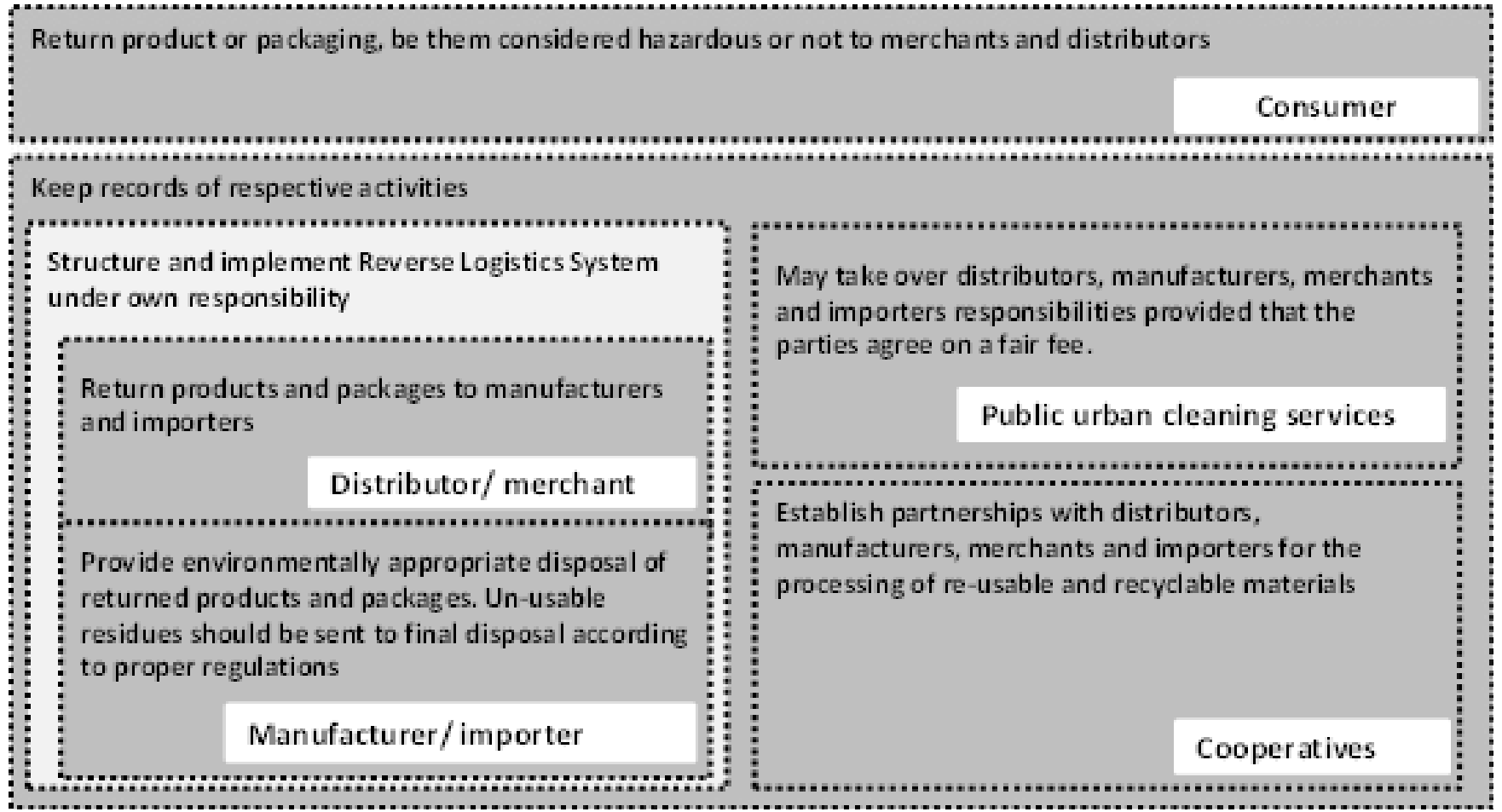

Figure 2 Responsibilities of participants in reverse logistics, according to Article No. 33 of PNRS.

Another important aspect related to PNRS is the establishment of industry agreements between participants of reverse logistics systems of prioritized areas as described in the law, as presented in Table 2.

Table 2 Industry agreements and targets for reverse logistics systems in under the Brazilian law.

\begin{tabular}{|l|l|l|}
\hline Type of waste & $\begin{array}{l}\text { Date of publishing } \\
\text { and time to comply }\end{array}$ & \multicolumn{1}{c|}{ Targets } \\
\hline $\begin{array}{l}\text { Packaging of } \\
\text { lubricant oil }\end{array}$ & $\begin{array}{l}\text { December 29,2011 } \\
45 \text { days }\end{array}$ & $\begin{array}{l}\text { Recovering 70\% of packaging material in the Southern, } \\
\text { Southeastern and Northeastern regions (except states } \\
\text { of Piaui and Maranhao) until 2014. }\end{array}$ \\
\hline Lamp Bulbs & $\begin{array}{l}\text { July 3, 2012 } \\
120 \text { days }\end{array}$ & $\begin{array}{l}\text { Progressive implementation of RLS within 5 years, } \\
\text { reach 20\% collection and treatment of the amount } \\
\text { sold in 2011 by 2017 }\end{array}$ \\
\hline Packaging & $\begin{array}{l}\text { July 4, 2012 } \\
120 \text { days }\end{array}$ & $\begin{array}{l}\text { Reach progressively higher targets from 22\% collection } \\
\text { and treatment in 2015 to 45\% in 2031. }\end{array}$ \\
\hline $\begin{array}{l}\text { Electrical and } \\
\text { electronic } \\
\text { equipment }\end{array}$ & $\begin{array}{l}\text { February 13,2013 } \\
120 \text { days }\end{array}$ & $\begin{array}{l}\text { Environmentally sound disposal of } 17 \% \text { (of the amount } \\
\text { sold in 2012) of used products by 2017. }\end{array}$ \\
\hline
\end{tabular}


Currently, the Brazilian legal framework prescribes different working groups within industries to act on specific categories of waste management. While the packaging of lubricating oil and lamp bulbs already have a specific CONAMA resolution (that has force of law) that sets environmental limits and standards, other types of waste such as other types of packaging and electronics do not. Those responsible for the RLS of CONAMA-regulated types of waste were induced (by government regulation) to organize themselves in less time and as a consequence achieved results sooner. This illustrates the importance of specific regulations for the consolidation of reverse logistics systems in different industries within the country.

\section{Introduction to reverse logistics systems}

The regulation of waste management in Brazil (discussed in the previous section) has fostered the organization of processes and the execution of activities that either did not happen before or if they did, it was in an independent and voluntary way. With the development of the National Policy on Solid Waste (Law No. 12305 of 2010) and other regulatory documents that were originated from it the necessity of designing and implementing reverse logistics systems became more pressing.

The fundamentals of reverse logistics systems have developed from bodies of knowledge that had already been well established such as traditional logistics, environmental management and waste management.

The design and implementation of RLS, besides requiring the mastery of concepts and tools of traditional logistics management also require specific knowledge about materials management, processes for allocation of waste to different destinations (reuse, remanufacturing, recycling and incineration) and disposal (landfill) and it requires certain manpower skills and availability of specific infrastructure.

Through federal legislation, in Brazil waste now should be managed as goods to be reinserted in supply chains whenever possible. This is virtuous both from the viewpoint of reducing the rate of consumption of nonrenewable resources and also of reducing polluting waste disposal in the environment.

The reverse channel (through which reverse flows pass) actors need to be recognized as providing value adding activities to the chains to ensure not only technical but also economic viability (and sustainability) of the whole process.

More than simply "reversing" direct logistic flows, reverse logistics systems require the reorganization of parts of the supply chain, the appropriate management of warehousing and transportation in reverse flows, the potential establishment of new businesses and the integrated management of reverse and closed-loop supply chains so as to ensure efficiency and effectiveness of the processes involved.

\section{Reverse logistics complexity}

Reverse logistics is complex, among other reasons, because of the diversity of areas it encompasses. Most of these areas are regulated in Brazil, although these regulations are not always consistent with each another. In our review, we found no references in the literature that pointed to a systemic solution for managing reverse logistics systems in Brazil.

We then reviewed national and international experiences as a reference for building a basic framework for the design and implementation of reverse logistics systems.

However, it became clear through the analysis of these cases that reverse logistics systems of some types of waste in developing countries have important specifics as compared to those found in developed countries.

Examples are the greater limitation of resources and perhaps most importantly, the presence guaranteed by law - of pickers of recyclable materials as an integral part of the system. This last factor (the pickers) is important and certainly contributes to the achievement of socio-environmental solutions (by helping both the social problem of lack of access to a minimum income by disadvantaged populations and the environmental problem of polluting waste disposal). However, the presence of pickers is also a factor that adds further complexity to the system. The proposed approach to reverse logistics systems presented in the next sections of this paper is based on the study of successful domestic and international real cases and well established concepts in the literature on direct logistics, environmental management and sustainable businesses. We hope it contributes with practitioners, researchers and students who are interested in the design and implementation of reverse logistics systems, 
by providing a conceptually robust yet practical framework that includes tools and concepts that can be adapted to different industries. Below some operational definitions adopted in this paper are presented.

\section{Supply chain management}

Supply chain management is the integrated management of the main business processes involved with the operation of facilities and the physical, financial and information flows from the original producers of basic raw materials through to the final allocation/disposal of post-consumption products in the production of goods, services and information so that value is added to all intermediate and final - supply chain customers and to other legitimate and relevant stakeholders in the chain (shareholders, employees, managers, community, government) (Corrêa, 2010).

\section{Logistics}

A significant part of supply chain management is logistics. According to the Council of Supply Chain Management Professionals (CSCMP) former Council of Logistics Management, logistics can be defined as:

"Logistics management is that part of supply chain management that plans, implements, and controls the efficient, effective forward and reverses flow and storage of goods, services and related information between the point of origin and the point of consumption in order to meet customers' requirements. [...] Logistics management activities typically include inbound and outbound transportation management, fleet management, warehousing, materials handling, order fulfillment, logistics network design, inventory management, supply/ demand planning, and management of third party logistics services providers." (www. cscmp.org, accessed April 12, 2013)

\section{Logistics and supply "networks"}

In a more recent conception, logistics management is addressed in the context, not of supply "chains" but of supply "networks" which in fact are interdependent, interconnected and sometimes integrated supply chains.
Networks, despite the increased complexity, have the potential to help achieve higher levels of efficiency by allowing consolidation of flows, greater economies of scale and integration of different supply chains.

Additionally, in recent decades managers and researchers came to realize that materials in supply chains do not only flow significantly in one direction (from the extraction of basic raw materials toward the consumer) but substantial volumes of material also flow in the reverse direction (from consumption back to production), mainly supporting activities of commercial returns, reuse, remanufacturing and recycling.

\section{Reverse Logistics}

The reverse flows go against direct flows - from the point of consumption back. Examples are materials and components of products or processes that, after being produced or consumed, are collected and transported back in supply networks to be reused or, recycled and reintroduced either in the same supply chain (such as in the case of aluminum cans collected after use and sent for recycling and turning into new aluminum cans) or other chains (such as in PET soda plastic bottles that are collected after use, recycled and used, for example, in the production of textile fibers).

Another example is the commercial return of products that flow in the reverse direction (upstream) to undergo cleaning, repair, remanufacture or other process to be eventually sent downstream to consumers.

Because they are flows that travel in the reverse direction of direct logistic flows in supply chains, the part of logistics that manages resources and processes relating to reverse flows is called "reverse logistics".

\section{Closed loop supply chains}

As the reverse flows normally seek the reinsertion of used materials back into production systems for reprocessing and resale, often these systems are also called "closed loop" supply chains (Guide e van Wassenhove, 2002). The closed loop supply chains therefore are those composed of direct and reverse flows, forming "loops" that make materials (used or not) to return to upstream points of the network for 
reuse or reprocessing for reuse.

\section{Sustainability and the Triple Bottom Line (TBL or 3BL)}

Pressures from markets and organized society (NGOs and government) have caused the concept of environmental sustainability to be incorporated as an important component of organizational management.

This led resource and logistic processes management to be adapted with the aim to reduce the "environmental footprint" generated by production systems. Initiatives in this direction include the greater use of concepts such as reduced resource use, reuse, recycling and better ways to dispose non-reusable/ non-recyclable waste. The reuse and recycling processes are usually integral parts of reverse logistics and closed-loop supply chains.

\section{The Triple Bottom Line}

When the goal of sustainability is introduced in the business environment, a relevant concept to be considered is the Triple Bottom Line (TBL or 3BL), a reference to the line that represents the final result in company financial statements. According to this notion, the production system's social, environmental and economic requirements should be managed in conjunction and in an integrated way (Elkington, 1997). TBL can also be understood as the balance between organization performance categories in relation to three "Ps": People, Profit and Planet. See Figure 3.

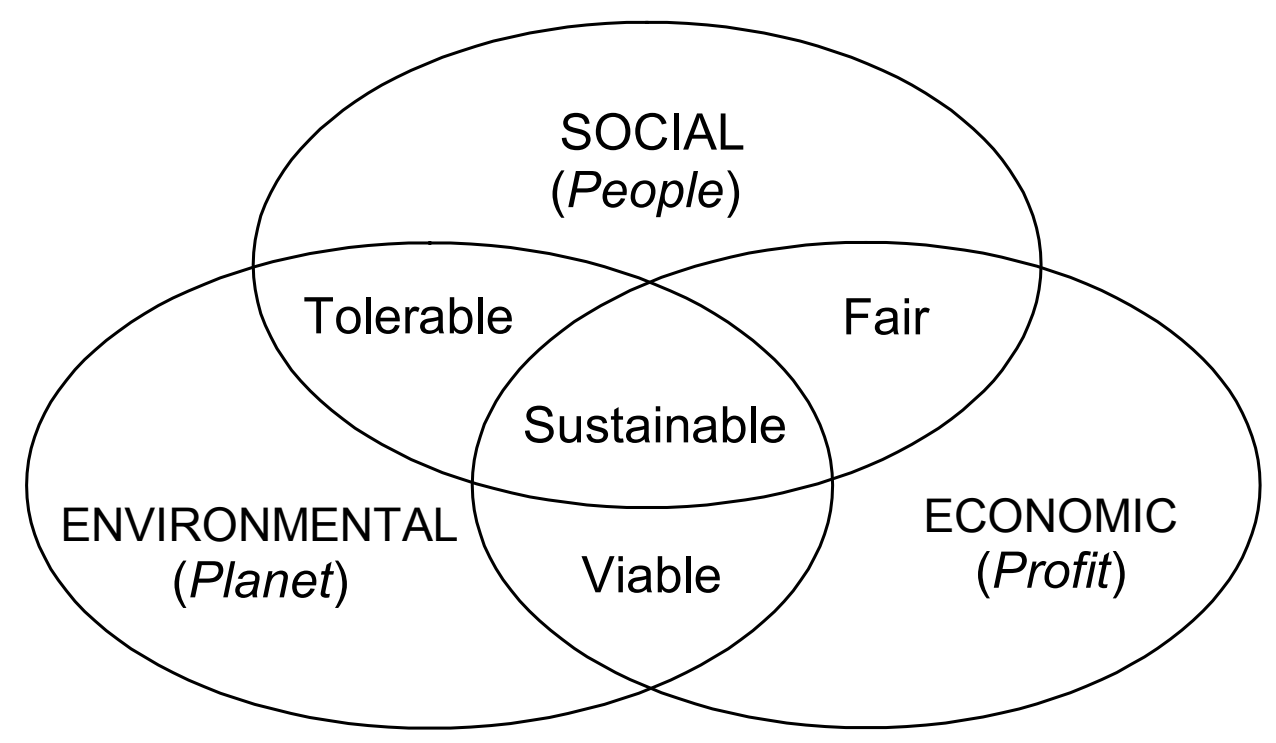

Figure 3 The triple bottom line and interactions

While the traditional focus of business is almost exclusively financial gain and competitive advantage in the marketplace, according to the notion of TBL they must also prioritize social responsibility and environmental preservation in addition to economic prosperity. The interactions between the social, environmental and economic spheres result in different aspects of sustainability. While the interface between the economic and social spheres prioritizes job creation and income that favor social aspects, the intersection between the economic and environmental spheres stresses environmental actions that are economically viable. In the interaction between the social and environmental spheres social activities are encouraged that do not impact the environment in an intolerably damaging way. Finally, the intersection of the three spheres represents sustainability in a broader sense.

\section{Sustainability as a source of competitive advantage}

Besides doing good for the world the use of more sustainable practices by organizations has also gradually been perceived as a potential source of strategic competitive advantage.

The reason is threefold. First, there is increasing concern by considerable number of consumers in 
relation to the potential damage that production, use and disposal of products and services can cause to the environment. Companies that have their image associated with more sustainable practices tend to be preferred by these consumers in their choice of supplier.

Second, a growing number of consumers also seem to be paying attention to the impact that manufacturers of products they consume have in society. The Brazilian successful cosmetics manufacturing Natura (visit for e.g. http://scf. natura.net/NaturaESociedade/) and the coffee giant Starbucks (visit for e.g. http://www.starbucks.com/ responsibility) are two examples. The initiatives that they have in place to reduce the environmental impact of their operations and to promote fair trade with the communities they purchase their raw material from are as emphasized in their marketing efforts and message as the quality of their products. This indicates how much some companies value the message of being a sustainable company as a potential source of competitive advantage.

Third, sustainability efforts can be cost effective because in many instances the use of recycled material in production is less costly than the use of virgin raw material. Recycling aluminum for e.g. can save $95 \%$ of the energy needed to make aluminum from bauxite ore. (http://www.aluminum.org/AM/ Template.. $\mathrm{fm}$ ?Section $=2012 \&$ CONTENTID $=33554$ \&TEMPLATE=/CM/ContentDisplay.cfm, accessed April 12, 2013).

Considering that electricity alone is generally accepted as representing about a third of the cost of aluminum, considerable savings can be obtained from investing in sustainability efforts related to closing the loop in aluminum supply chains. With lower costs, a company can pass on part of the benefit to customers by lowering prices thereby gaining competitive advantage.

Several companies now include in their annual reports aspects such as emissions, water and energy consumption and, environmental impact as metrics for assessing the organization's environmental performance. Companies set targets for the reduction or mitigation of negative impacts (such as the impact of emissions) and, on the other hand, seek the reinforcement of positive impacts (such as job creation and improved quality of life).

The pursuit of sustainability can occur through prevention, mitigation of impacts (economic, social and environmental) or the practice of compensatory measures. An example of compensatory measures is the trading of carbon quotas by criteria established by the Clean Development Mechanism - CDM (see http://unfccc.int/kyoto_protocol/mechanisms/ clean_development_mechanism/items/2718.php accessed April 03, 2013 for details).

\section{Bio-logical and industrio-logical systems and, sustainability}

Unruh (2008) proposes an interesting approach that he calls 'Biosphere Rules', for the treatment of natural resources by production systems. According to the author, production systems should adopt a bio-logical approach (according to which resources and structures of different ecosystems are used to support life in its different dimensions), in contrast to the usual industrio-logical approach to production. The latter assumes you can freely use a wide range of synthetic materials to be processed in production processes - which is not necessarily sustainable.

The author proposes three basic rules to support a bio-logical approach that would lead to more sustainable production systems:

\section{- $\quad$ Rule 1. Using a parsimonious palette}

Surprisingly, despite the existence of more than 100 chemical elements in the periodic table, Nature uses basically four - carbon, hydrogen, oxygen and nitrogen - to produce all living things. The parsimony in resource usage in natural systems promotes recycling, in contrast to the use of a wide variety of materials and low potential recyclability of most products produced in industrial systems.

\section{- $\quad$ Rule 2. Cycle up from standardization}

The 'standardization' in biological systems ensures that raw materials are always available to organisms, with no need for complex processes of screening or sorting. In Nature, from the death of an organism the biosphere recovers materials and efficiently and constantly reinserts them in other processes, for the same original use or better. This is called up-cycling. The down-cycling instead destroys (at least part of) the original value, as sometimes it occurs with the reduction in quality of products produced from recycled material. The biosphere has no down-cycling processes, but industrial systems do. The biosphere also uses 'planned' biological obsolescence for the execution of recycling processes. The process of formation of new organisms occurs from elements resulting from the degradation and 
death of older ones. Thus, the productive potential of newer and healthy organisms ensures ongoing system efficiency.

- Rule 3. Exploration of the power of "platforms" From the simplest organisms, the biosphere has been undergoing a continuous evolutionary process that makes organisms more complex and at the same time, more efficient and adapted to the environment in which they operate. In other words, the basic design of organisms undergoes constant adaptation in order to adjust to adversity or facilities that the environment provides. The design is the platform for building the biodiversity that we see today.

Similarly to bio-logical systems, industrio-logical systems have also explored the power of platforms.
In this respect there is an analogy with the computerized systems - platforms (systems) that have a wide operating range of applications in a constant process of adaptation.

\section{Circular Economy}

Somewhat similarly (in the sense that this approach also uses a natural analogy - here ecology - for treating industrial cycles), the Ellen MacArthur Foundation proposes the concept of "circular economy".

The principle of circular economy (see Figure 4) is guided by the concept of Industrial Ecology (Erkman, 1997) and comprises the interaction of different agents on different systems.

\section{The circular economy: An approach for a resource-constrained and environmentally sensitive world}

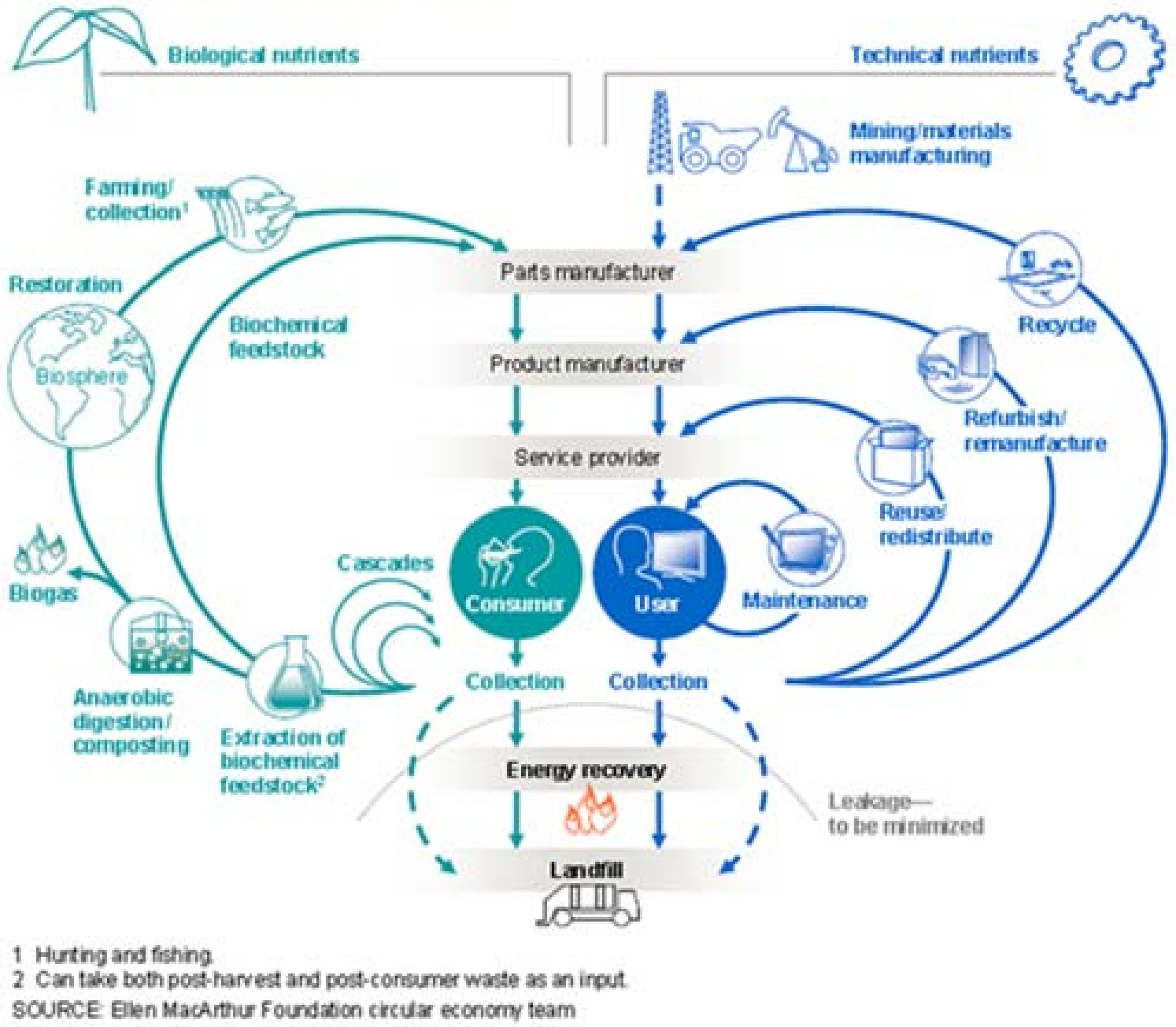

Figure 4 The Circular Economy

Source: Helen MacArthur Foundation (http://www.ellenmacarthurfoundation.org/circular-economy/circular-economy/newreport-towards-the-circular-economy-vol-2 accessed February 18, 2013.) 


\section{Environmental footprint}

The mitigation of environmental impacts is one of the main aspects to be managed in the search for better sustainability practices. From the identification of current and potential environmental damage resulting from production as well as from the measurement of ecological footprints (harmful effects to Nature) of products and processes, it is possible to trigger actions to reduce uncertainty and increase efficiency in the management of sustainable production processes.

Figure 5 illustrates the various flows - direct, reverse and closed-loop that many contemporary companies have to manage.

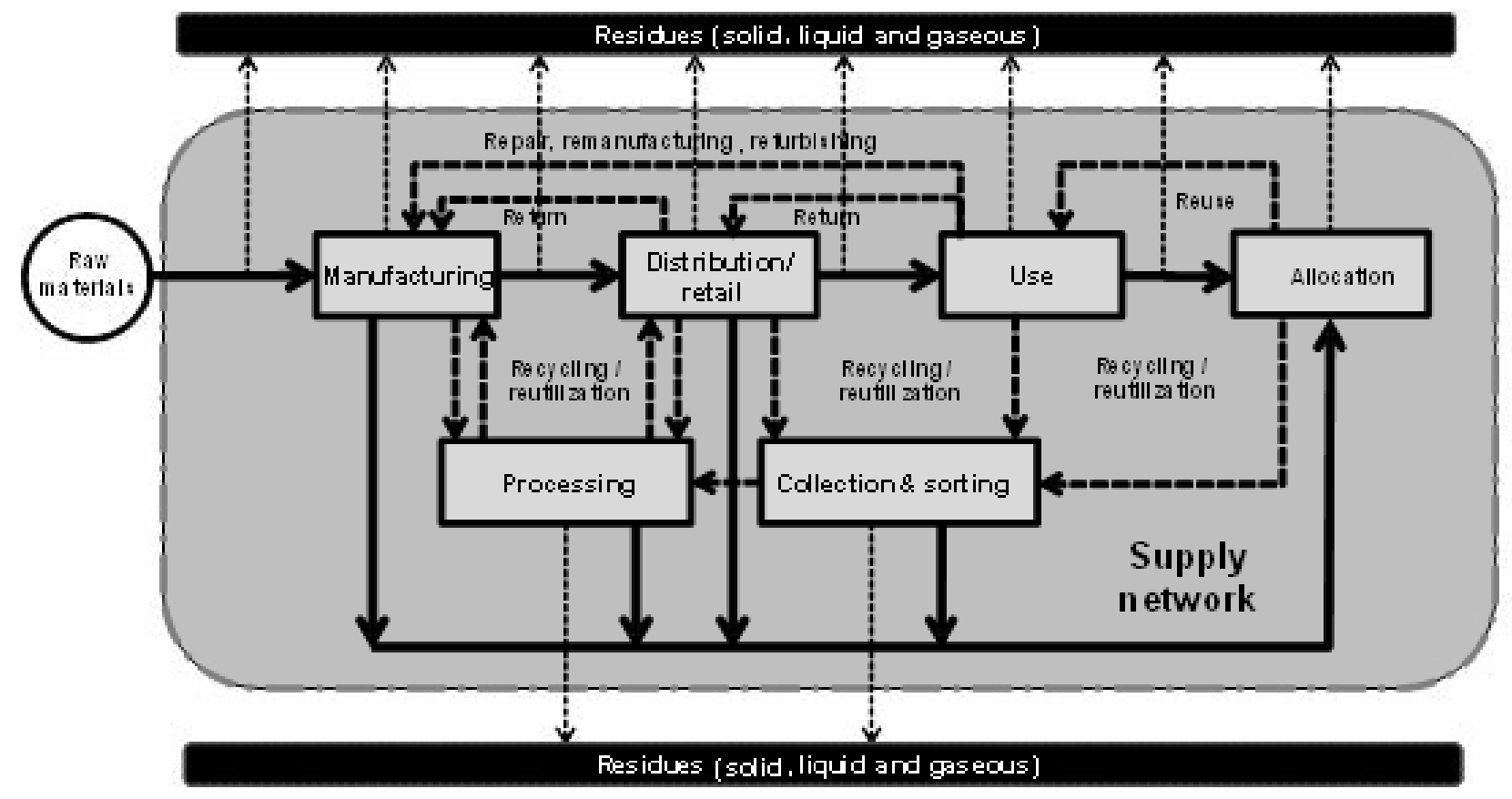

Environment

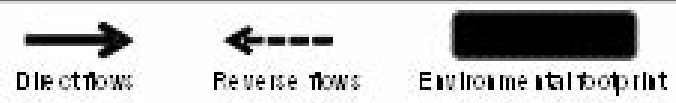

Figure 5 Direct, reverse flows and closed-loop supply chains. (Xavier and Corrêa, 2013, adapted from Corrêa, 2010)

\section{The direct and reverse flows in logistics}

Production systems start from obtaining raw material to be processed. Raw materials can be classified as natural (wood, water, minerals), compound (composites, fibers and pellets), solid metallic (ferrous and nonferrous) and solid nonmetallic (ceramic, polymer and semiconductor). Natural resources can be classified as renewable and non-renewable. The concept of sustainability depends to a great extent on prioritizing the use of renewable resources and recycling waste, byproducts, co-products and secondary materials.
Below some definitions used in this study in relation to materials and products are presented.

- Raw materials/components: any substance from which a product is manufactured and of which it is necessarily a part. They normally come originally from Nature having or not gone through subsequent processing. They can be classified as renewable and non-renewable.

- Co-products or secondary products: they necessarily result from the production process of the main product. Although not a part of the final product they can have significant value. In 
the supply chain of biodiesel for instance glycerin and pie are examples of co-products of biodiesel that can be used as input in the chemical industry and as animal feed respectively. According to ISO 14044 2009, co-products are two or more products resulting from the same elementary process or production system.

- Byproducts: also resulting from the production process of the main product but with significantly lower market value. In the case of beef production from cattle, bones, horns and hooves would byproducts.

- Intermediate products: products of one production process that are subsequently applied to (and ends up being a part of) another product of another process. The tires that will subsequently be assembled in new cars, for instance constitute an intermediate product of the automotive industry.

- Waste, emissions or effluents: undesirable products from production processes that in most cases result in and require cost mitigation actions. In specific cases these however can be avoided or can even be turned into a source of revenue for the production process if they can be (possibly processed and/or) sold.

- $\quad$ Secondary raw material: waste (solid, liquid or gaseous) material recovered through recycling.

During the production stages, reverse logistics can be used in the process of reusing byproducts and co-products. While in the post-consumption stages reverse logistics is used in the processing of products and/ or its parts for potential reuse as secondary raw materials.

\section{The role of waste pickers in RLS}

In Brazil, the work of pickers of recyclable materials has found significant support through public policies that were recently established by the government. However, despite being a recognized profession that is fundamental to waste management in Brazil, there are still relatively few qualified picking professionals in some specific segments of recycling.

\section{The picking activity}

The implementation of waste management systems or more specifically recyclable materials management programs in Brazil includes laws that favor the active participation and organization of waste material pickers through the establishment of associations and cooperatives.

According to a World Bank report (Hoornweg and Bhada-Tata, 2012), globally the recycling industry uses labor from more than two million pickers working informally. The (Brazilian) National Movement of Recyclable Materials (MNCR) is a social movement that independently defends the interests of pickers and focuses on enabling the control of the recycling chain by workers (see http:// www.mncr.org.br, accessed April 14, 2013) for details). The MNCR estimates that 800 thousand pickers were operating in Brazil in 2013, of which 65000 are MNCR-affiliated pickers.

In research published in 2011, IBGE (Brazilian Institute of Geography and Statistics) found that about $30 \%$ of the 5,565 Brazilian municipalities recognize the participation of waste pickers in waste sorting through associations and cooperatives (http://saladeimprensa.ibge.gov.br/en/noticias?v iew=noticia\&id=1\&busca=1\&idnoticia=2260). In addition, $5 \%$ of the municipalities recognize the participation of independent pickers.

The presence of large numbers of pickers of recyclable materials is characteristic of developing countries but rarely observed in developed countries. Pickers however already used the reverse logistics 'logic' even before the term was coined, before the area started to be more widely studied in academia and certainly before governments started to articulate their regulatory mechanisms.

Law No. 11445 of 2007 establishing the National Sanitation Policy (PNSB) is the first regulatory instrument in Brazil to support the activities of those pickers who work through legally constituted associations and cooperatives.

This law amends official government bidding mechanisms favoring pickers associations and cooperatives, by waiving the need for them to take part in the formal government bidding process regarding recycling. In its Article 57 that law amends Law No. 8666 of 1993 which lays down the rules for procurement and administrative contracts under the Powers of the Union, States, Federal District and Municipalities. The law, in its Article 24, considers waiving bidding: 
"in contracting the collection, processing and marketing of recyclable or reusable urban solid waste in areas with selective garbage collection system, done by associations or cooperatives formed exclusively by low income individuals who are recognized by the government as pickers of recyclable materials using equipment compatible with the applicable technical, environmental and public health standards." (Law No. 8666 of 1993, section XXVIII, Section 24).

Importantly, both PNSB and Decree No. 5940 of 2006 (which regulates the disposal of recyclable materials by federal offices) and PNRS emphasize the management of recyclable materials by cooperatives or associations of pickers.

During the 90s and the 2000s Brazilians were proud of the fact that the country occupied the first place in the world ranking of percentage of collection and recycling of aluminum cans after consumption.
However, the finding that the leadership in recycling cans was a result of unfavorable social factors led to a reanalysis of the path taken. While in countries like the U.S. and Japan recycling occurs for reasons more related to environmental awareness, cultural aspects or more advanced and efficient recycling technology, in countries like Brazil high recycling rates in the last decade primarily reflect unfavorable social and economic condition of a significant portion of the population.

The percentage of recycled aluminum cans in Brazil today is even more impressive, with many pickers organized in associations and cooperatives where they work under better conditions and therefore they are more capable of performing their tasks according to basic good practices of industrial organization.

Nearly $97 \%$ of aluminum cans consumed in the country today is recycled, more than in countries such as Japan, Argentina, United States and European countries (see Figure 6).

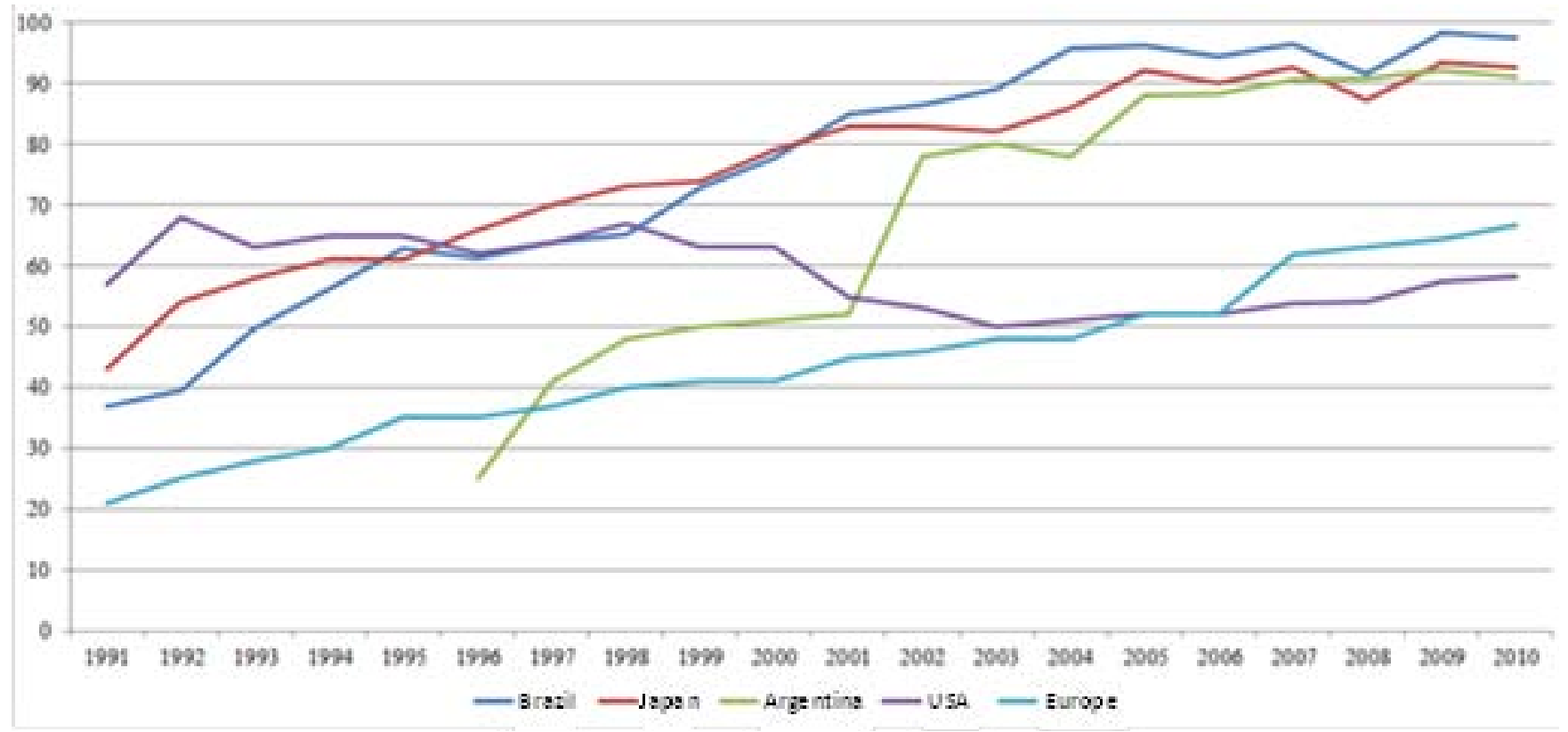

Figure 6 Indices of beverage aluminum cans recycling for various countries (\%)

Source: Brazilian Association of Manufacturers of Highly Recyclable Cans (Abralatas), 2011. 
Unlike developed countries, some countries in Latin America, Asia and Africa have available low cost manpower for the activity of picking recyclables. However, despite the activity of picking to be legally regulated in Brazil, many picking workers are still not formally recognized and don't have the minimum infrastructure, training and protective equipment.

The unsanitary conditions in which a large portion of these workers operate lead to the frequent occurrence of diseases and as a consequence to declined productivity.

According to data from the Brazilian Aluminum Association (Abal), per capita consumption of aluminum in Brazil was $5.0 \mathrm{~kg} /$ inhab.year in 2007, considering the total estimated amount for all applications, such as equipment and components, artifacts, construction and packaging.

This figure is quite impressive, considering that the average total waste disposal per capita (aluminum and others) is approximately $380 \mathrm{~kg} /$ inhab.year, of which about $340 \mathrm{~kg} /$ inhab.year are collected, according to data from the "Overview of Solid Waste in Brazil" (ABRELPE, 2011).

Integration with producers, even indirectly, may represent significant gains for both pickers and producers alike. One example is the interaction with industries like Tetrapak (http://campaign.tetrapak. com/lifeofapackage/br/na, accessed April 10, 2013).

\section{Picking activity in the developing world}

In India, the National Environmental Policy, established in 2006 recognizes the informal sector and encourages the collection and recycling of waste.

In China mechanisms for licensing pickers have been developed (Chaolin, 2012), but this does not appear to have been effective since as a result only 80 pickers joined the licensing in the country in the following year.

Different countries are experimenting with alternative ways of working of pickers in managing their solid waste. The model of social organization such as the one adopted in Brazil requires the maturation of the related regulatory mechanisms, as well as being sure about its suitability to the local practice of recyclable materials trading.

\section{Cooperatives of picker for solid waste recycling}

Some studies have studied different aspects of the formation of cooperatives of pickers of recyclable materials (Vieitez and Dal Ri, 2000; Novaes, 2004). In this regard, Dias (2009) studies cooperative networks in the cities of São Paulo and Belo Horizonte, in Brazil. Dias' study sought to analyze cooperatives as a solution to social exclusion and concludes that recycling in large scale in Brazil was only made possible as the waste collection and sorting tasks proved feasible and cost effective. The author argues that from start these were tasks performed by people whose low labor cost compensated the cost with needed facilities and technology investments in the rising recycling industry.

Environmental aspects of vulnerability and low qualifications of those who work in cooperatives and associations end up indirectly impacting the cost of production in this segment. Assuming that markets are formed from economic interest and social relations, cooperatives acting in an integrated manner have the potential of increasing economic gains and in parallel, meeting social demands.

\section{Pulverized sources of recyclable materials}

By organizing in networks picker cooperatives gain economies of scale and enable the access to recyclable material in volumes and frequency that are compatible with the dynamics of the industrial world production lines and volumes.

Generally cooperatives work with a mix of waste materials that in certain cases is not even all converted into secondary raw material. Part of the volume received is still sent to landfills for lack of minimum volumes that would be of interest to the recycling industry. It may not be economically viable for the recycling industry to provide and pay for the transport to collect small amounts of input from a large number of cooperatives.

So agreements (in most cases, informal) were developed in which the industry actors stipulate minimum volumes for the purchase and transport of post-consumption material.

Similarly to most companies the ones that operate in reverse chains with recycling or refurbishing postconsumption materials and products require that 
the supply of inputs (in this case, waste) has some degree of predictability for production planning purposes.

In this aspect, the cooperatives of pickers operating in networks prove advantageous for all members of the chain. Waste management from a massive organization of waste pickers working in cooperative networks has the potential to foster profitable supply chains in the recycling industry.

\section{The design of reverse logistics systems}

As discussed above, reverse logistics is not restricted to issues related to environmental management nor is limited to waste management. The construction of a reverse logistics system requires continuous improvement and learning about different aspects related to three main aspects:

- $\quad$ Setting up collaborative production systems; - $\quad$ Compliance of reverse channels to legal and normative frameworks and,

- Monitoring and traceability of material flows involved.

Reverse logistics involves a broader approach than the mere activity of transportation of waste from the post-consumption stage. Similarly to direct logistics it comprises logistics operations (transport, storage) but in the "reverse" direction. Some well-known concepts apply to reverse logistics, as suggested in Figure 7.

\section{Reverse Logistics System}
Production
Consumption
Discard
Allocation
Final disposal

\section{Direct logistics}

Reverse logistics

\section{Recycling}

\section{Remanufacturing}

\section{Reverse manufacturing}

\section{Reuse}

\section{Final disposal}

Figure 7 Coverage of key concepts related to the reverse logistics system. 
The possibilities for the treatment and allocation of materials and post-consumption products increasingly include actions that prioritize the reuse, recycle, refurbishment and reinsertion of materials back in supply chains. Figure 7 shows the relationship between the allocation alternatives and the reverse logistics system. While recycling may be present from the direct logistics activities through to reverse logistics operations, reuse and remanufacturing occur in the post-consumption and are more linked to the reverse logistics operations.

The reverse logistics system encompasses both direct logistics activities such as transportation and storage of the product after production (stage at which there may already be the need to return materials) and reverse logistics activities (starting with the use) leading to the alternatives for allocation of products after use: reuse, remanufacturing, recycling, incineration and landfill final disposal.

In the alternatives of incineration and landfill there is the extinction of the possibility of subsequent use of any physical 'output' although there is usually the possibility of energy recovery from incineration. Remanufacturing is an alternative that restores the original properties of parts and products for the purpose of reinserting them into stages of manufacturing / assembly (of remanufactured parts) or consumption (remanufactured finished products).

Recycling uses process and technological innovations to allow the reinsertion of materials into the manufacturing stage.

Reuse does not necessarily include commercialization; there is often a social component in the reuse of products and materials. Reusable parts and products are reinserted into the consumption stage of the chain.

The RLS's should be an integral part of the business model of manufacturing and service companies that decide to design and implement them.

As in most cases companies are already operating but see themselves in need to implement their RLS at a certain point in time, it seems plausible that in these cases they start the RLS design process by analyzing the company's business model and strategy, with an emphasis on logistics processes already in place.

\section{The problem of obtaining material inputs in reverse logistics systems}

Reverse logistics has specifics in relation to direct logistics. An important one is how to obtain inputs for its processes.

In direct logistics obtaining material inputs is a predictable process that depends only upon the amount and type of products to be processed. Material is "pulled" from suppliers based on the process needs to meet demand.

In reverse logistics, processing is mainly "pushed" by the availability (which is much less predictable than the availability of "virgin" raw material supplied by vendors) of post-consumption and post-production recyclable products.

In other words, the uncertainty about the availability of material inputs is greater in reverse chains, where one cannot predict with accuracy and advance the amount of material to be received within a specified period and as required by the specific production process.

The greater uncertainty directly impacts (by increasing) reverse logistics operational costs relative to traditional logistics.

Reverse logistics systems aim to reduce the uncertainty of such availability of inputs, increase the scale and hence reduce the production costs of reverse logistics and reverse production. Economies of scale are achieved through industry agreements that allow for transportation load consolidation and cooperative resource management and logistics operations.

\section{A conceptual framework for the development of RLS}

Reverse logistics systems encompass direct and reverse logistics activities and can be understood as a collaborative arrangement that is strongly influenced by legal and normative mechanisms related to waste management.

The conceptual framework to support the design and implementation of RLS that we propose is based on six steps: 
Step 1. Identification of the motivation for developing RLS

The most obvious motivation of companies for the implementation of a RLS is compliance to legal requirements. In Brazil, these requirements are established by the National Solid Waste Policy (PNRS). In Latin American countries in general, motivation, beyond legal compliance, may include the possibility of generating income for individuals in poverty. For this reason, the main regulatory instruments of such countries contemplate and support the pickers' role in such systems. In developed countries on the other hand, economic or market aspects and/or public environmental awareness are more often considered as motivators (in conjunction with legal requirements). According to Cline et al. (2012) in the United States the RLS consolidation occurs primarily for economic reasons.

The identification of the motivation for the implementation of the organization RLS will guide the next steps.

Step 2. Preliminary market analysis

Market data collection and analysis represent fundamental activities in business management. The same goes for the design and implementation of RLS. After the identification and analysis of motivation (Step 1) mechanisms should be identified for data collection. Such data will generate information both about the availability (volume, quality and reliability) of postproduction and post-consumption material as well as about the market for its reprocessing and reinsertion into the supply chain of origin or in another chain.

\section{Step 3. Acquisition of knowledge}

This step should be about compiling information that will both allow the characterization of the RLS and subsidize future strategic and operational decisions. Such information should consider:

- Specifics of environmental
regulations;
- $\quad$ Industry;
involved in the process;

- $\quad$ Frequency, regularity and volumes of waste generated;

- $\quad$ Technological options for potential minimization, recycling, reuse and recovery;

- $\quad$ Identification of (and mapping out) the supply network components (carriers, producers, recyclers, among others).

Step 4. System characterization

RLS's can be classified according to:

- $\quad$ Speed of the product cycle;

- $\quad$ Volumes generated;

- $\quad$ Potential for recyclability of waste;

- $\quad$ Degree of vertical integration versus outsourcing activities;

- Relative location of the consumer markets of recovered materials;

- Degree of the supply network consolidation and economies of scale and,

- Location and relative distance of the units involved.

The characterization of the SLR will drive design and implementation decisions.

Step 5. Selection of the basic framework (reference model) This step comes from the need for specific answers for each analyzed issue. The basic reference model proposed in the following sections of this article is based on the concept of LCA (Life Cycle Analysis, see http://acv. ibict.br accessed April 12, 2013) because from our analysis this is perhaps the most versatile and easily applicable model found in the current literature. Figure 9 shows a schematic of our proposed framework for the design and implementation of RLS.

\section{Step 6. Implementation}

Actions shall be implemented in accordance with the criteria described by the basic selected reference model. Our research work used three successful case studies: Correios (Brazilian postal services), TGestiona and the pesticide package RLS in Brazil to analyze the key aspects for the design and management of RLS (for details see Xavier and Corrêa, 2013. For space limitations, the case studies are not presented in this article). Aspects of the implementation process of RLS are also discussed more in detail a head. 
Figure 9 Conceptual framework (reference model) for reverse logistics systems

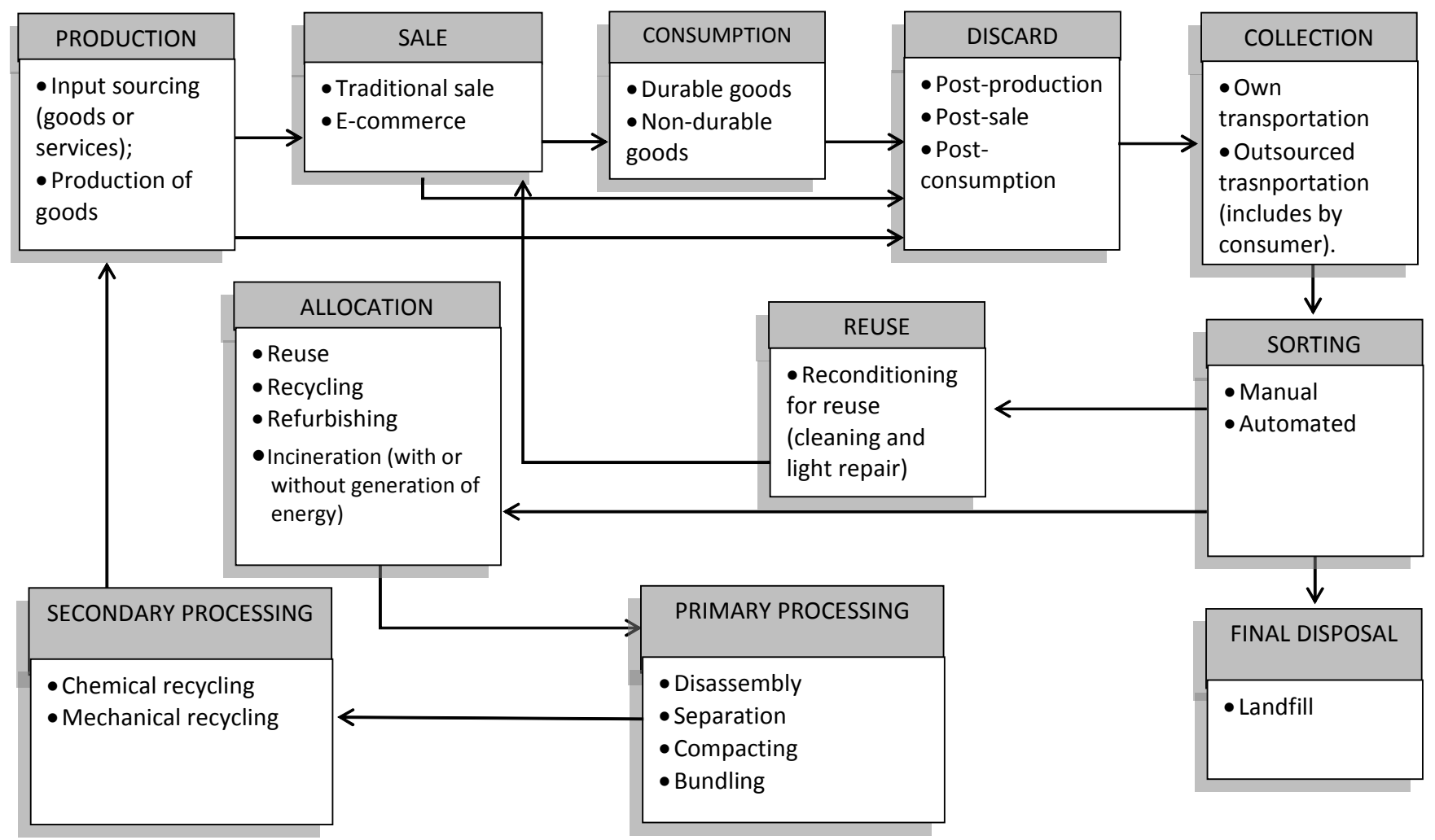

Our framework consists of a generic representation of steps that are applicable to RLS development in different industries. Specifics on the type of material processed, available resources and approaches should then be considered for the adoption of a specific RLS design.

According to the specific supply chain being analyzed, some aspects can be adjusted or removed from the model as needed.

It is noteworthy that, as with all logistics operations, between each step shown in Figure 8 transport, storage and transshipment should be considered as needed.

\section{The implementation of reverse logistics systems}

According to article 21 of PNRS, reverse logistics (systems) can be implemented by three instruments: industry agreements, regulations and terms of engagement. Below is a proposed roadmap for the implementation of the RLS from the basic design described above.
Product design for the environment

Waste management and RLS development should actually start in the product design stage. The creative use of new materials, the design of the product itself and the interaction between the product and the environment and, with consumers should also be evaluated from the perspective of sustainability.

The design of an RLS without considering this step can result in a system that is only capable of dealing with the consequences and not the causes of problems, emphasizing correction rather than prevention.

One example comes from Coca-Cola. The company has recently developed two types of packaging for their products.

The first was a promotional packaging in PET resin produced in opaque gold and red colors and sold in the Christmas period.

This package, after consumption was rejected by pickers who faced difficulty in sorting and in the level of acceptance of the material by recycling 
companies - they considered the pigments as being contaminants to conventional PET resin derived from petroleum.

The second type was the so called plantbottle, a soft drink container produced with $22.5 \%$ resin derived from sugar cane, 25\% recycled PET resin with the remainder being virgin PET resin. The longer term goal in developing the plantbottle according to the company is to achieve oil independence in making their packaging. Unlike the Christmas bottle, plantbottles are transparent and recyclable along with conventional PET packaging (Stoklosa, 2011). While in the first case the product design negatively impacted the reverse chain in social and environmental terms, in the second the package has a much greater potential for the achievement of sustainability.

The same reasoning applied to product design can be applied to production process design with the goal of providing economic, environmental and social benefits to the reverse logistics system. See McDonough and Baumgart (2002) for a reference about designing products and processes for sustainability.

\section{Discard}

Disposal starts from the definition of the product "end of life". End of life here does not necessarily mean the extinction of all product functionalities. A product may still be functional but it may be considered obsolete for not having the same performance as a new product, for example.

For the prediction of life span and disposal volumes it is important to understand the product consumption patterns. More predictability will allow the management of post-consumption products and materials to be more in line with the requirements of reverse logistics in terms of capacity, location of units, process planning and as a result, efficiency. Identifying consumption patterns for instance allows the identification of types of products and materials consumed in a particular region or country. This in turn allows better decisions in terms of the location of collection and recycling units that will meet the RLS needs.

The life span of a product is defined by estimating their ability to maintain functionality over time. This is related to the behavior of the material during use and varies with the composition of the product, where, how and under what conditions it is being used and a range of other variables related to a greater or lesser extent to the degradation of its components.

Moreover, a product may still exhibit its functionalities and yet be discarded to be replaced by another for reasons of fashion or technical obsolescence.

The disposal phase of post-consumption products and materials is today one of the main challenges of reverse logistics systems. It is at this stage that the process presents most difficulties in specific industries such as pharmaceutical, electronics and lamp bulb where consumers tend to keep postconsumption materials or improperly dispose them, impairing the subsequent steps of collection and allocation.

\section{Collection}

Collection can be performed by using own transport modes (under the responsibility of sorting units, recyclers or manufacturers) or third parties (including the delivery of the product by the consumer to delivery points), as shown in Figure 10.

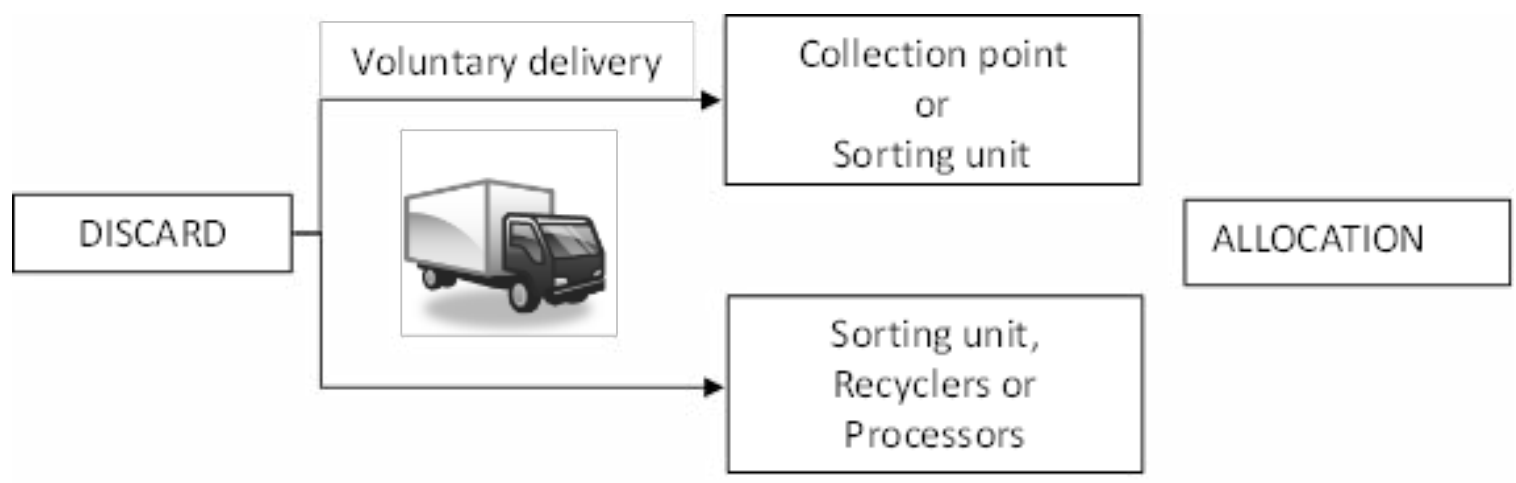

Figure 10 Transport logistics collection 
Delivery can also be done by the consumer directly to recycling companies or producers (processors), but these categories represent an exception and higher cost as compared to other alternatives.

While direct logistics distribution flows from one or a few companies to many consumers ( 1 to $n$ ) in reverse logistics exactly the opposite (n to 1 ) occurs: many consumers must return their products to one or a few companies - for this reason, the unit cost of returning post-consumption items is relatively high. Collection systems also vary according to specific aspects such as distance, type of material to be transported and type of processing required. Some ways to define collection systems are:

- $\quad$ By type of material: practiced in segments such as the recycling of PET and aluminum. Such type allows the extraction of value from consolidation of large volumes of the same material; - By product brand: practiced by some companies that choose to protect the brand and/ or data. Although more expensive, this category of collection provides greater security for manufacturers that choose to protect their brands. Generally, it is used with products having high value density or relevant information to be protected;

- By consortium of companies: different companies in the same segment, through associations, cooperatives, NGOs jointly realize the collection of post-consumption products and materials. This method applies to the packaging of pesticides and lubricating oil for instance;

- $\quad$ Simple type: it consists in collecting various types of materials or products simultaneously followed by sorting. Material may be received or collected in pre-established sites. It is the most common form among picker cooperatives of recyclable materials that, in turn, are suppliers of recyclers;

- $\quad$ Second party: performed by recyclers and producers using their own fleet of vehicles. They collect post-consumption materials or products from sorting cooperatives' or associations' recycling units.

\section{Sorting}

It involves assessment of products in terms of functionality and classification into allocation alternatives such as "reconditioning/reuse", "recycling" and "remanufacturing". Products with features that are missing or faulty are evaluated for possible replacement of parts or components and sent for potential remanufacturing or repair. Fully functional products that do not require repair are only checked, cleaned, cosmetically touched, repackaged and routed back for sale.

\section{Maintenance or Repair}

Technical maintenance or repair in order to restore product features. Often the commercialization of products after repair is done in partnership with the producers of the original product, including product warranty.

\section{Primary Processing}

It basically consists in the steps of disassembly, sorting, compaction and bundling of material. This step aims at adding value to materials and parts for forwarding to the recycling steps.

\section{Secondary Processing}

It involves chemical (for recovering raw materials) or mechanical (fractioning, grinding or reduction of parts or materials for use as input material) recycling processes. In Brazil, this step cannot be performed by associations and cooperatives of pickers since they do not have the environmental permit for treatment of waste, effluents and emissions possibly resulting from this process.

\section{Reinsertion in the supply chain}

Reinsertion can occur in the original supply chain as input material (such as aluminum cans, which can be indefinitely made into other aluminum cans) or other supply chains (such as the insertion of used conventional plastic bottles into the textile products supply chain). The amount of residues disposed in landfills should be as small as possible since it is the only portion that is not amenable to reuse and only results in mitigation costs to the system and damage to the environment.

\section{Monitoring and tracking}

Shamsuzzoha and Helo (2011) define monitoring as the collection and management of real-time information on the processing and distribution of a particular product and tracking as collecting and retaining information about the history of the life cycle of processed and distributed product, as well as of its components.

Monitoring in reverse logistics can mean managing the movement of collection vehicles in real time in order to identify the occurrence of deviations or to allow rerouting due to traffic congestion. Tracking, 
in turn, is not intended to monitor movement in real time, but to retrospectively retrieve data about routes followed and responsibilities in cases of failure in the transportation process e.g. due to theft or accident.

In reverse logistics systems monitoring is important as it allows follow up of cargo collection and payment of post-consumption products and materials. Unlike direct logistics, reverse logistics has no strict requirements as to delivery times. Rather, they have requirements as to collection volumes.

Because of shipping and processing costs recyclers are more concerned with receiving minimum volumes than setting deadlines. On the other hand, the originators of post-consumption products and materials seek to reduce their costs through the elimination of costly storage i.e. intermediate storage points to which material is sent frequently and in smaller volumes.

Monitoring tends to be more relevant for products in the food and pharmaceuticals industries. These are required by law to comply with standards in relation to the risk of contamination. Monitoring is also important to materials with high value density. At each step of the process the product, its origin and destination in the value chain must be identified. It is a fundamental activity in the management of global supply chains with products distributed in several countries. The identification of the composition of raw materials in products has become a usual requirement in international negotiations, especially in the food sector.

Tracking enables the assignment of responsibility along the supply chain, increasing thereby the reliability of the whole process.

\section{Final remarks}

This work does not intend to be definitive or generalizable to one hundred percent of the situations. However, it tries to make a contribution to the evolution of this promising, exciting and relatively new knowledge area: reverse logistics systems in Brazil.

Through literature review, review of related Brazilian legislation, analyses of 3 of the few Brazilian (relatively) mature cases and a number of international cases, we organized the key concepts involved and went ahead to propose a simple yet robust and practical framework that can be an interesting starting point for students and professionals interested in the design and implementation of reverse logistics systems that are consistent with applicable law so that the resulting RLS can contribute to increase the levels of sustainability of supply chains in Brazil.

In order to achieve a stage of full development, reverse logistics systems in Brazil as a knowledge field still has a long way to go. It is still in its infancy if compared to the more mature older sister - direct logistics. Our contribution aims to accelerate this evolution process so that the benefits of attaining the stage of full development can be achieved more quickly. For more details on the concepts and the model presented here please see Xavier and Corrêa (2013).

\section{REFERENCES}

ABAL (2008). Relatório de Sustentabilidade da Indústria do Alumínio - 2007. 3aㅡ edition. São Paulo. Available in: http://www.abal.org.br/ servicos/biblioteca/rel_sustentabilidade_0607. asp. Acessed September 14, 2012. (in Portuguese).

ABRALATAS (2011). Indices da reciclagem da lata de alumínio para bebidas 1991-2011. Available: http://www.abralatas.org.br/common/ html/grafico5.html. Acessed September 14, 2012. (in Portuguese).

ABRELPE (2011). Panorama de Resíduos Sólidos no Brasil. Available: http://www.abrelpe.org. br/Panorama/panorama2011.pdf. Accessed September 14, 2012. (in Portuguese).

BOWMAN, R. J. (1995) Green logistics. Distribution, Vol 94, no 6.

CASTELLS, M. (1999) A sociedade em rede. São Paulo: Paz e Terra. (in Portuguese).

CHAOLIN, D., (2012) Want China Times. Available: http://www.wantchinatimes.com/ news-subclass-cnt.aspx?id $=20121006000006 \& c$ id=1103. Accessed December 15, 2012.

CLINE, A., Le MAY, S., HELMS, M.M. (2012). Testing the Framework for Reverse Logistics: 
The Case of Carpet. Supply Chain Management Educators' Conference. Atlanta, USA.

CORRÊA, H.L. (2010) Gestão de Redes de Suprimento. Atlas, São Paulo. (in Portuguese).

DE BRITO, M., DEKKER, R., 2003. A Framework for Reverse Logistics. ERIM Report Series Research in Management. Roterdam. Available at: $\quad$ http://repub.eur.nl/res/pub/354/ERS-2003045-LIS.pdf. Accessed April, 2013.

DIAS, S.L.F.G., 2009. Catadores: uma perspectiva de sua inserção no campo da indústria de reciclagem. Tese de Doutorado. Programa de Ciências Ambientais - PROCAM/USP.

ELKINGTON, J. (1997) Cannibals with forks: the triple bottom line of 21st century business. Oxford: Capstone.

ERKMANN, S. (1997), Industrial ecology: an historical view. Journal of Cleaner Production, Vol. 5, No. 1-2, pp. 1-10.

GREENFUDGE, B. (2010). UK Government and European e-waste illegally dumped in Africa. Available at http://www.greenfudge. org/2010/09/13/uk-govt-and-european-e-wasteillegally-dumped-in-africa/. Accessed November 10, 2012.

GUIDE e VAN WASSENHOVE, 2008. The Evolution of Closed-loop Supply Chain Research. INSEAD. Available in: http://www.insead. edu/facultyresearch/research/details_articles. cfm?id=25174 . Accessed January 15, 2013.

HOORNWEG, D., \& BHADA-TATA, P. (2012). A Global Review of Solid Waste Management. What a Waste,15.

MCDONOUGH, W. AND BRAUNGART, M. (2002) Cradle to Cradle, remaking the way we make things. Melcher Media. New York.

BRUNDTLAND REPORT (1988) Nosso Futuro Comum. Comissão Mundial sobre o Meio Ambiente e Desenvolvimento. Rio de Janeiro: Editora da Fundação Getulio Vargas.

NOVAES, H.T. (2004) Os Simões Bacamarte da Economia Solidária. Textos para Discussão da ITCP. Unicamp. Available in: http://web.tau.org. ar/upload/89f0c2b656ca02ff45ef61a4f2e5bf24/ Os___Sim_es_Bacamarte_da_Economia_ solid_ria_ITCP.pdf Accessed October 10, 2012. (in Portuguese).

SHAMSUZZOHA, A.H.M. E HELO, P.T. (2011). Real-time Tracking and Tracing System: Potentials for the Logistics Network. Proceedings of the 2011 International Conference on Industrial Engineering and Operations Management.

STOKLOSA, K. (2011). Recyclers are still facing challenges with commingled PLA and PET containers. Subtle Differences. Available: http:// www.recyclingtoday.com/Article.aspx?article_ id=119146 accessed April 11, 2012.

UNRUH, G.C. (2008) The Biosphere Rules. Harvard Business Review, February.

VIEITEZ, C. G.; DAL RI, N. M. (2000) Virtualidades político-sociais das organizações econômicas dos trabalhadores. Organizações e Democracia, Marília, Vol 1, no 1. (in Portuguese).

XAVIER, L.H. e CORRÊA, H.L. (2013) Sistemas de Logística Reversa: Criando cadeias de suprimentos sustentáveis. Atlas. São Paulo. (in Portuguese). 


\section{AUTHOR'S BIOGRAPHY}

Henrique Luiz Corrêa: Professor of Operations and Supply Chain Management at Rollins College - Crummer Graduate School of Business, since 2006. Awarded in 2011/2012 the prestigious Rollins College Bornstein Faculty Scholarship Award, Professor Correa previously taught at the Fundacao Getulio Vargas Business School, São Paulo, Brazil (1998-2006) and at the University of São Paulo (Escola Politécnica), also in Brazil (1986-1996). He has also served visiting appointments at the University of Warwick (UK), IESA (Venezuela), INCAE (Costa Rica), University of Texas at San Antonio (USA), IE Business School (Spain), Porto Business School (Portugal), Fundação Dom Cabral (Brazil), Federal University of Rio de Janeiro (Brazil), among other institutions. His research interests include global supply chain management and flexible operations. He has published extensively in academic journals including the International Journal of Operations and Production Management, Computer Integrated Manufacturing Systems, International Journal of Logistics Systems Management, Journal of Manufacturing Technology Management, International Journal of Business Excellence, Journal of Operations and Supply Chain Management and Latin America Business Review. Correa has authored and co-authored nine books and text-books in the fields of operations strategy, service operations, operations management and global supply chain management, having sold more than 100,000 copies in Brazil. He has consulted with companies such as Unilever, General Motors, 3M, Hewlett-Packard, Embraer, Brazil Foods, Monsanto, Inter-Bev, Wella (Procter \&Gamble), Pepsico, Whirlpool (Embraco), Natura Cosmetics, Boehringer-Ingelheim Pharma, Wyeth-Whitehouse among others. Professor Correa served as vice president for the Americas in the Production Operations Management Society (POMS) (2005-2008) and as founding President of the College of Human Behavior in Operations Management of POMS. He also serves in the editorial board of the International Journal of Operations and Production Management, Revista de Administração de Empresas da EAESP/FGV, Journal of Operations and Supply Chain Management and, an ad hoc reviewer for many journals in the field of OM. He is a certified professional in production and inventory management (CPIM) by APICS (USA).

Lucia Helena Xavier: Biology Undergraduate at Federal University of Rio de Janeiro (1997), MSc (2001) and Ph.D. (2005) in Production Engineering at the Federal University of Rio de Janeiro. She has experience in Production Engineering with emphasis in Environmental Engineering, mainly in the following areas: Environmental management, Environmental performance (ISO 14031) and Reverse Logistics. She has consulted in environmental audit with companies as Coca-Cola, Piraquê, Darrow and Bayer. Worked in partnership with the University of Oviedo (Spain) in Reverse Logistics and Environmental Management. Fellow PRODOC/CAPES Program for Graduate in Production Engineering UFPB in 2006. Research Assistant in Environmental Management and Reverse Logistics at Fundação Joaquim Nabuco (Fundaj) - Social Research Institute, since 2007. Associate Teacher of Reverse Logistics at Federal University of Pernambuco (UFPE) since 2009 and MBA Teacher of Environmental Planning and Management at Catholic University of Pernambuco (Unicap) since 2010. Post-doctoral on Reverse Logistics at University of São Paulo (2011-2012). Papers published in academic journals: Omega and Pesquisa Operacional. Co-authored two books about management and environmental assessment. 